\title{
On-farm Characterization of Barley (Hordeum vulgare L.) Landraces in the Highlands of North Gondar, Ethiopia
}

\author{
Daniel Tadesse $^{1 *}$, Wuletaw Mekuria ${ }^{2}$, Beyene Derso ${ }^{3}$ and Tazebachew Asres ${ }^{4}$ \\ ${ }^{1-4}$ College of Agriculture and Rural Transformation, University of Gondar, Ethiopia
}

\begin{abstract}
Barley is an important crop for the North Gondar highlands of Amhara Region, Ethiopia. To assess the characterization of barley landraces, 180 farmers from six villages in three districts of north Gondar zone were selected and surveyed. With regard to distribution status, most of the recorded landraces of barley were endangered. The main end uses of barley in the study area were kolo, beso, tela, injera, korefe, kita and kinche. According to farmers, the main criteria for selecting a variety was varietal characteristics mainly in the pre-harvest operation. The main characteristics for doing so are length of the spike, size of the seed, amount of seed per spike, ability to withstand disease, stand of the plant, tillering ability, number of rows, and germination ability. The majority of farmers renew the seed mostly between 1 and 3 years. The main reason for renewing are production decline, to prevent landraces from elimination and to increase productivity. The majority of the farmers stated that they do not store seeds for long period of time associated with the fact that they hardly produce any surplus that can be stored for longer years. In barley production, women have roles of joint decisions on number and types of varieties to grow, plot allocation, and storage. However, postharvest processing is mainly decided by women. Farmers have proverbs associated with how much women are important in saving and maintaining barley landraces and make ready when the need arises. Hence, barley genetic resources should be conserved before they are lost and farmers' variety selection criteria should be incorporated in the modern breeding of barley. The active involvement of women in the maintenance and improvement of landraces should not be undermined in the modern crop improvement programs.
\end{abstract}

Key words: Ethiopia, barley, landrace, characterization, traits

\section{Introduction}

Local knowledge of landraces/farmer's varieties develops over generations of first-hand observation of crucial features, their appearance and performance in a variety of environments, through good and bad rainy seasons (Guarino, 1995). Extended and continuous cultivation as well as maintenance and use of indigenous crop varieties by local farmers have led them to better understand the traits; environmental requirements (soil qualities, rainfall, altitude, temperature, etc.), special features of productivity and post harvest processes as well as the special utility values of the varieties have carefully maintained for years in a very innovative way both as individuals and as members of an interacting community (Asfaw, 1997).

Access to a range of crop genetic variability is critical to the success of breeding programs, and consequently to food security and human nutrition (Toledo, 2006). Landraces are considered more locally adapted and genetically variable than modern cultivars (Ceccarelli and Grando, 2000). They contribute to agricultural production around the world, particularly for the rural poor in marginal environments as source of seed for next season planting (Ceccarelli and Grando, 2000). Farmers make crop maintenance decisions based on combinations of factors including adaptability, yield, socio-cultural values and food traditions as well as nutritional values. These decisions affect the genetic diversity of crop populations (Ranjil, 2010). Farmers' maintenance approaches have allowed the continual evolution of landraces diversity in their area of adaptation. This diversity has been the key to food security for generations and an invaluable resource for crop improvement activities around the world. 
The value of the evolutionary services delivered by on-farm conservation, while grounded at the community level, is connected to broader social and ecological landscapes where diverse landraces are maintained by different farming communities and interlinked to various degrees through seed systems (Samberg et al., 2013). These landraces are distributed across different types of environments, thus facing diverse selection pressures from environmental factors as well as from human management and preferences.

Smallholder farmers, both men and women, continuously carry out experimentation on the crops grown in their locality based on gastronomic criteria (Oosterhout, 1993) and storability (Teshome et al., 1999) as well as agro-morphological characters. While performing various field activities, farmers carry out evaluation progressively to assess the performance of the crops throughout the growing period (Berg, 1993). Smallscale farmers' choose to grow more than one variety of a given crop simultaneously reflects their need to address numerous concerns, which no single variety would satisfy (Bellon, 1996). Farmers have multiple concerns that are reflected in multiple criteria for selection and variety ranking. Thus, farmer's management of their varieties and their role in seed selection activities are crucial to agricultural production, conservation and enhancement of the genetic resources. Farmers often noted varieties that had become "tired" and needed replacing; they gave their tired seed to farmers in cooler and more fertile areas for multiplication (Almekinders et al., 1994).

The culinary and varietal preferences, generally maintained by women, have a major influence on knowledge, selection, and use of agricultural biodiversity (Howard, 2003). Researchers are now finding that women's contribution is greater than previously perceived. In the literature, few studies investigate specifically the role of women in seed processing, storage, and exchange. Other researchers have focused on specific aspects of women's work in seed management, such as selection (Mulatu and Zelleke, 2002). However, the gender dimensions in the intra household decision-making process were seldom addressed in seed management research.

There are a number of studies that deal with how local farmers manage their seed, select varieties, renew tired seeds and decision making of the varieties in the family. An experiment conducted at Koga of West Gojjam Zone in Ethiopia confirmed diversity among 49 malt barley genotypes (Tilahun and Alemu, 2017). Many studies have shown that farmers in developing countries have intimate knowledge of environmental processes and make rational resource management decisions based on that knowledge (Olango et al., 2014). Although the northern Gondar highlands are potential barley production areas and harbor great diversity of land races, there is no documented study. For this reason, it is important to study and document diversity of barley, farmers' variety selection criteria, management of seeds, renewal of tired seeds, contribution of barley in the livelihood, local seed exchange systems and intra-household decision making systems.

\section{Materials and Methods \\ Description of the Study Areas}

North Gondar zone is selected for the following reasons: (i) barley is one of the first food crops in the zone in terms of area coverage, production and importance, (ii) the zone is one of the micro-center of diversity for barley, and hence ideal sites for studying. In North Gondar, the highland districts of major barley producers are Wogera, Dabat, Debark, Janamora, Lay Armachiho and Gondar Zuria. Among these six districts three of them namely Wogera, Dabat and Debark were selected purposively due to high production potential. Six kebeles, Adisgie Miligebsa and Gomia from Debark, Woken and Talak mesik from Dabat and Daber Lideta and kossoye from Wogera were selected purposively for the purpose of study. In order to assess on farm characterization barley landraces, survey research was undertaken. These were semi-structured interviews (a household survey through structured questionnaire) and focused group discussion.

\section{Research Design}

The design of the study was non-experimental types based on various data collection methods. With respect to the objectives and nature of the research questions of the study, both qualitative and quantitative data collection methods were employed.

The survey design consisted three stages. In the first stage, three study districts were purposively selected in consultation with North Gondar Zone department of Agriculture and field observations. The three representative districts (Debark, Dabat and Wogera) were purposively selected from the potential barley 
producing districts of the zone in terms of large coverage for barley. In the second stage, two villages were purposively selected from each district in consultation with district agricultural experts with the major criteria being higher importance of barley in terms of area coverage and consumption preference. Finally, respondent households were selected randomly in each kebele in probability proportional to size.

In the third stage, 180 farmers were selected by equal distribution method which means 60 from each districts or 30 household heads were randomly selected from a list of farmers in each selected Kebeles. Women household heads and elders were purposely involved to ensure the representativeness or household diversity in terms of knowledge and seed management.

Both qualitative and quantitative data types were collected in this study. The data used were collected from both primary and secondary sources. Informal and formal surveys were used to collect the primary data. The informal survey was conducted through focus group discussions, interviewing key informants and development agents. The discussions were entirely participatory. The structured and semi-structured questionnaire were pre-tested and used to perform the formal survey. An interval schedule was pre-tested and necessary amendments were made. In the formal survey, farmers were interviewed by the pre-tested questionnaire after interpreted to the local language (Amharic). The survey was conducted from February to March, 2016. Six enumerators who had the local knowledge and language were trained and recruited. The trained enumerators under the supervision of the researcher interviewed those sampled farmers.

At the household level, information were collected on reasons for selecting a variety over the others, when in the seed and varietal selection take place, how seed of barley is renewed and replaced and role of women in barley production. The respondent farmers were also asked to list all the varieties they know, classify and evaluate their varieties based on their name, number of rows, meanings, preferred/non preferred characteristics and uses. Sayings associated with barley were documented. In addition, respondents classified their varieties as popular (abundant), rare, and endangered on the basis of area shared yields of varieties. "popular" is defined as those varieties grown by many households over large areas. "Rare" types are those grown by few households on very small plots, and "endangered" types are grown either in mixed cultures or by only a few households in neighboring kebeles.

Key-informant interviews were conducted with development agents of the districts. Focus-group discussion was conducted with selected farmer groups specially elders and female heads to document farmers' knowledge of the barley varieties and their ranking preference. The issue of women's role in seed management was addressed not only during the household survey but also in the group discussions.

\section{Results and Discussion}

\section{Farmers' Choice of Barley Varieties}

Farmers in the study districts purposely maintain landraces to address various needs. The main traits farmers use to prefer a given variety over the other were maturity, yield potential, suitability for animal feed, grain size, grain color, spike length, tillering capacity, market demand, condition of the soil and product volume. According to Eticha $\mathrm{F}$ et al. (2008), the selection criteria for landraces of barley reflect adaptations to changing farming conditions, and responses to the socio-economic and cultural factors that shape farmers priorities. With regard to distribution status, most of the recorded landraces of barley were endangered, some are rare and only three varieties are popular (Table 1). This indicates that the need for conservation of the landraces found in the farmers' hand. Diversity in end-uses is one of the important factors that influence the maintenance and genetic diversity of a particular crop. Different landraces are preferred for specific end-use. The main end uses of barley in the study area were kolo, beso, tela, injera, korefe, kita and kinche. A study made on enset showed that the biggest uses of landraces are for kocho, bulla, amicho, fiber and medicine (Zerihun et al., 2016). A study made on wheat indicated a wide range of variations among landraces for the traits studied which help farmers an opportunity to make a choice of genotypes that fit their purpose (Zewdie et al., 2014).

Kolo is roasted grain prepared from dehulled barley. Beso is solid food prepared from roasted barley flour and water. Tela is alcoholic beverage prepared from gesho, malt, roasted grain and kita. Tela is the most common and preferred local beverage which is made mainly from barley. Injera is leaven bread made from 
raw grain flour with the dough fermented for 2-4 days and baked on clay pan. Korefe is alcoholic beverage prepared from gesho, malt and lightly roasted barley grain and kita. The study district inhabitants drink korefe early in the morning and it act as a food though it is a beverage. Kita is instant bread baked from unfermented dough of raw grain flour. Kinche is a dish prepared from cracked raw barley grains. Most of the landraces are suitable for kolo, beso, tela, injera. The preferred landraces for korefe are Derg gebs, Weremenie, Semeno, Andita and Nech gebs. Abat gebs, Tegedie belga and Nech gebs are the preferred landraces for kita. The landrace Tegedie belga is preferred for kinche. Kinche is not common diet for north Gondar highlands.

Table 1. Characteristics of major barley varieties in relation to preferred and non preferred traits

\begin{tabular}{|c|c|c|c|c|}
\hline $\begin{array}{l}\text { Variety } \\
\text { Name }\end{array}$ & $\begin{array}{l}\text { Distribution } \\
\text { status }\end{array}$ & Preferred traits & Non preferred traits & End uses \\
\hline Teklie gebs & Rare & $\begin{array}{l}\text { Early maturing; suitable for variety of soil } \\
\text { types; palatable straw quality; high- } \\
\text { medium grain yield }\end{array}$ & $\begin{array}{l}\text { Attacked by birds; lodging } \\
\text { problem }\end{array}$ & Kolo, beso \\
\hline Derg gebs & Endangered & $\begin{array}{l}\text { High-medium grain yield; early maturity; } \\
\text { large grain size; palatable straw quality }\end{array}$ & $\begin{array}{l}\text { More straw; low flour; } \\
\text { prefers fertile soil }\end{array}$ & $\begin{array}{l}\text { Korefe, beso, } \\
\text { kolo }\end{array}$ \\
\hline Woremene & Rare & $\begin{array}{l}\text { Early maturity; high product volume; long } \\
\text { spike; drought tolerant; } \\
\text { palatable straw quality }\end{array}$ & $\begin{array}{l}\text { Low grain yield; prefers } \\
\text { fertile soil; not palatable for } \\
\text { injera }\end{array}$ & $\begin{array}{l}\text { Injera, beso, } \\
\text { korefe, kolo }\end{array}$ \\
\hline Semeno & Endangered & $\begin{array}{l}\text { Long spike; high tillering capacity; high } \\
\text { grain yield; } \\
\text { palatable straw quality; early maturing }\end{array}$ & $\begin{array}{l}\text { More awns and less flour; } \\
\text { short stature }\end{array}$ & $\begin{array}{l}\text { Injera, tela, } \\
\text { kolo, korefe, } \\
\text { beso }\end{array}$ \\
\hline Andeta & Endangered & $\begin{array}{l}\text { The product is good both by its quantity } \\
\text { and quality; demanded by market; long } \\
\text { spike; mature early }\end{array}$ & $\begin{array}{l}\text { Small flour; more awns; } \\
\text { straw is not palatable; } \\
\text { shattering problem during } \\
\text { harvest; attacked by birds }\end{array}$ & $\begin{array}{l}\text { Korefe, kolo, } \\
\text { injera, tela, } \\
\text { beso }\end{array}$ \\
\hline Abat gebs & $\begin{array}{l}\text { Endangered } \\
\text { /Rare }\end{array}$ & $\begin{array}{l}\text { High grain yield; long spike; palatable } \\
\text { straw quality; tolerates water logging; } \\
\text { mature early }\end{array}$ & $\begin{array}{l}\text { Prefers fertile soil; more } \\
\text { awns and less yield }\end{array}$ & $\begin{array}{l}\text { Kita, tela, } \\
\text { injera, kolo }\end{array}$ \\
\hline Nech gebs & $\begin{array}{l}\text { Endangered/ } \\
\text { Rare }\end{array}$ & $\begin{array}{l}\text { Demanded by market specially by its } \\
\text { color; not attacked by birds; taller in } \\
\text { height; high grain yield }\end{array}$ & $\begin{array}{l}\text { Sensitive to lodging; does not } \\
\text { need heavy rain; sensitive to } \\
\text { frost and weed; prefers fertile } \\
\text { soil }\end{array}$ & $\begin{array}{l}\text { Beso, kolo, } \\
\text { korefe, injera }\end{array}$ \\
\hline Awura gebs & Rare & High grain yield; palatable for food & More awns; small flour & $\begin{array}{l}\text { Injera, beso, } \\
\text { kolo }\end{array}$ \\
\hline Shegie gebs & Rare & $\begin{array}{l}\text { Demanded by market mainly by the color } \\
\text { of its grain; long spike }\end{array}$ & $\begin{array}{l}\text { Low grain yield; lodging } \\
\text { problem }\end{array}$ & Beso, tela \\
\hline $\begin{array}{l}\text { Netela } \\
\text { belga }\end{array}$ & Rare/Popular & $\begin{array}{l}\text { Early maturity; drought tolerant//drought } \\
\text { relief crop/; suitable for double cropping }\end{array}$ & More awns; low grain yield & $\begin{array}{l}\text { Tela, injera, } \\
\text { kolo }\end{array}$ \\
\hline Shewa gebs & Endangered & $\begin{array}{l}\text { High yielder; long spike; tolerant to frost; } \\
\text { white seed }\end{array}$ & $\begin{array}{l}\text { Small product volume; late } \\
\text { maturity; prefers fertile soil }\end{array}$ & Injera, tela \\
\hline $\begin{array}{l}\text { Akiya/senef } \\
\text { kolo/ }\end{array}$ & $\begin{array}{l}\text { Endangered/ } \\
\text { Rare }\end{array}$ & $\begin{array}{l}\text { High yielder; used mainly for kolo; early } \\
\text { maturing; frost tolerant }\end{array}$ & $\begin{array}{l}\text { Single row; prefers fertile } \\
\text { soil }\end{array}$ & Kolo \\
\hline Tikur gebs & $\begin{array}{l}\text { Endangered/ } \\
\text { Rare }\end{array}$ & $\begin{array}{l}\text { High yielder; tolerate wind and frost; } \\
\text { preferred for tela }\end{array}$ & $\begin{array}{l}\text { Not preferred by market and } \\
\text { is cheap; prefers fertile soil; } \\
\text { injera is black; more awns }\end{array}$ & $\begin{array}{l}\text { Kolo, tela, } \\
\text { injera }\end{array}$ \\
\hline Bozie belga & Popular/Rare & Early maturity; tolerate frost and drought & $\begin{array}{l}\text { Not preferred by market; } \\
\text { more awns }\end{array}$ & Tela, beso \\
\hline Marwey & Rare & Early maturing; preferred by the market & $\begin{array}{l}\text { Prefers fertile land; needs } \\
\text { fertilizer }\end{array}$ & $\begin{array}{l}\text { Tela, injera, } \\
\text { animal feed }\end{array}$ \\
\hline Belga & Rare & $\begin{array}{l}\text { Grow over large area; high yielder; early } \\
\text { maturing }\end{array}$ & $\begin{array}{l}\text { The product is not quality } \\
\text { since attacked by weed }\end{array}$ & $\begin{array}{l}\text { Injera, } \\
\text { beverage, } \\
\text { animal feed }\end{array}$ \\
\hline $\begin{array}{l}\text { Tegedie } \\
\text { belga }\end{array}$ & Popular & $\begin{array}{l}\text { Early maturing; withstand frost and heavy } \\
\text { rain by bending the spike down; long spike }\end{array}$ & $\begin{array}{l}\text { Low yielder; the injera is } \\
\text { hard }\end{array}$ & $\begin{array}{l}\text { Tela, kolo, } \\
\text { injera, kita, } \\
\text { kinche, beso }\end{array}$ \\
\hline $\begin{array}{l}\text { Dinble } \\
\text { nech gebs }\end{array}$ & Rare & $\begin{array}{l}\text { High yielder; early maturing; tolerate to } \\
\text { wind, frost, drought }\end{array}$ & Prefers fertile soil & $\begin{array}{l}\text { Injera, Tela, } \\
\text { kita, kolo }\end{array}$ \\
\hline
\end{tabular}

According to farmers' response, the choice to select a variety depends on a number of factors including seasonal condition, varietal characteristics, multiple uses, market demand, a combination of the above factors and other reasons as well. Of these, varietal characteristics (31.7\%) play the major role (Table 2). 
Table 2. Choice to select a variety

\begin{tabular}{|l|r|r|}
\hline Reason to select and plant a given variety & $\mathrm{N}$ & \multicolumn{1}{|c|}{$\%$} \\
\hline Seasonal condition & 22 & 12.2 \\
\hline Varietal characteristics & 57 & 31.7 \\
\hline Multiple use & 30 & 16.7 \\
\hline Market demand & 23 & 12.8 \\
\hline Seasonal condition and multiple use & 6 & 3.3 \\
\hline Varietal characteristics and multiple use & 12 & 6.7 \\
\hline Other reason & 5 & 2.8 \\
\hline $\begin{array}{l}\text { Seasonal condition, varietal characteristics, multiple use and } \\
\text { market demand }\end{array}$ & 25 & 13.9 \\
\hline Total & 180 & \\
\hline
\end{tabular}

Farmers may undergo seed and variety selection during different stages of the plant. They stated that, seed and varietal selection occur during pre harvest (45\%), post harvest $(35.6 \%)$ and both pre-harvest and postharvest (19.4\%). During post harvest, seed may be selected before threshing, during threshing, after threshing, during storage and a combination of the above. Almost half (54.5\%) of the respondents select seed after threshing (Table 3).

Table 3. Seed and variety selection

\begin{tabular}{|l|r|r|}
\hline Stage in the crop for undertaking seed and varietal selection & $\mathrm{N}$ & \multicolumn{1}{|c|}{$\%$} \\
\hline Pre- harvest & 81 & 45.0 \\
\hline Post- harvest & 64 & 35.6 \\
\hline Both pre-harvest and post-harvest & 35 & 19.4 \\
\hline Total & 180 & \\
\hline Seed and varietal selection during postharvest & & \\
\hline Before threshing & 14 & 14.1 \\
\hline During threshing & 9 & 9.1 \\
\hline After threshing & 54 & 54.5 \\
\hline During storage & 10 & 10.1 \\
\hline Before threshing, during threshing, after threshing and during storage & 10 & 10.1 \\
\hline During threshing, after threshing and during storage & 2 & 2.1 \\
\hline Total & 99 & \\
\hline
\end{tabular}

The traits mainly used by farmers to select barley varieties in the field (pre harvest) are length of the spike, size of seed, amount of seed per spike, ability to withstand disease, stand of the plant, tillering ability, number of rows, germination ability. They also used the traits early maturity, ability to withstand wind, ability to withstand drought, inability to be attacked by birds, color of the seed, and weight of spike in to consideration when selecting barley varieties.

The traits mainly used by farmers to select barley varieties after harvest but before threshing are weight of seed, length of the spike, ability to withstand shattering during harvest, number of rows, not damaged by disease, and having large harvested products per a given area. The traits mainly used by farmers to select barley varieties during threshing are ability of the seed immediately separate from the husk by using cattle threshing and wind, weight of the seed, quality of the product (without husk), usability of the byproduct for feed, length of the spike, having uniform size and color of the seed.

The traits mainly used by farmers to select barley varieties after threshing are weight of the seed, quality of the seed for various purposes, quality of the floor, size of the seed, uniformity of the seed, purity of the seed, and color of the seed. The traits mainly used by farmers to select barley varieties during storage are inability to be damaged by various means (like pests, diseases), weight of the seed by checking with their hand, ability to store for long period of time without damage, quality of the seed, and amount of the floor during milling.

Although farmers may select barley varieties at different stages of the growth, they give more attention to some traits more than others. The main traits are suitability for food, high yield potential, early maturity, 
suitability for feed, many end uses, large number rows (4-6) and tillering ability. In order to differentiate one landrace from another farmers use a variety of traits. The main traits are maturity, yield, number of rows, suitability for feed, spike length, seed color.

The majority of farmers $(91.7 \%)$ renew seed while some $(8.3 \%)$ do not renew seed. From those that renew seed, seed renewal mostly occurs between $1-3$ years (Table 4). Farmers stated that the main reasons to renew barley landraces are when the ability to give product decline, in order to prevent landraces from elimination, to increase productivity, purity decline as the time passes by and if not renewed the germination ability declines. Those farmers that renewed barley landraces were asked how they do so. They stated that they renew by sowing in a fertile soil, exchanging with other farmers, sowing the seed by using compost, selecting large sized seeds and multiplying and selecting those plant with good stand and performance in the field.

Table 4. Renewal of seed

\begin{tabular}{|l|r|r|}
\hline Renewal/replacement of seeds & $\mathrm{N}$ & \multicolumn{1}{|c|}{$\%$} \\
\hline Yes & 165 & 91.7 \\
\hline No & 15 & 8.3 \\
\hline Total & 180 & 100.0 \\
\hline Frequency of renewal of seeds & & \\
\hline 1-3 years & 135 & 81.8 \\
\hline 4-6 years & 27 & 16.4 \\
\hline 7-10 years & 3 & 1.8 \\
\hline Total & 165 & \\
\hline
\end{tabular}

\section{Barley seed source and replacement}

Barley seed source

In each cropping season, each household decides which variety, how much seeds and in which piece of land to grow in their farming area. In most of the cases farmers in the study area use their own farmer-saved seeds although they may obtain seeds through exchange or purchase. In this study, we found that $89.4 \%$ of the respondent farmers retain their produce and depend on their own seeds while $5 \%$ and $4.4 \%$ buy away from homestead and in their neighbor village, respectively. Limited number of respondents $(0.6 \%)$ exchange either in their village or away from homestead. This showed those farmers now adays purchase their seed directly rather than the old days exchange of seeds by other seeds (Figure 1).

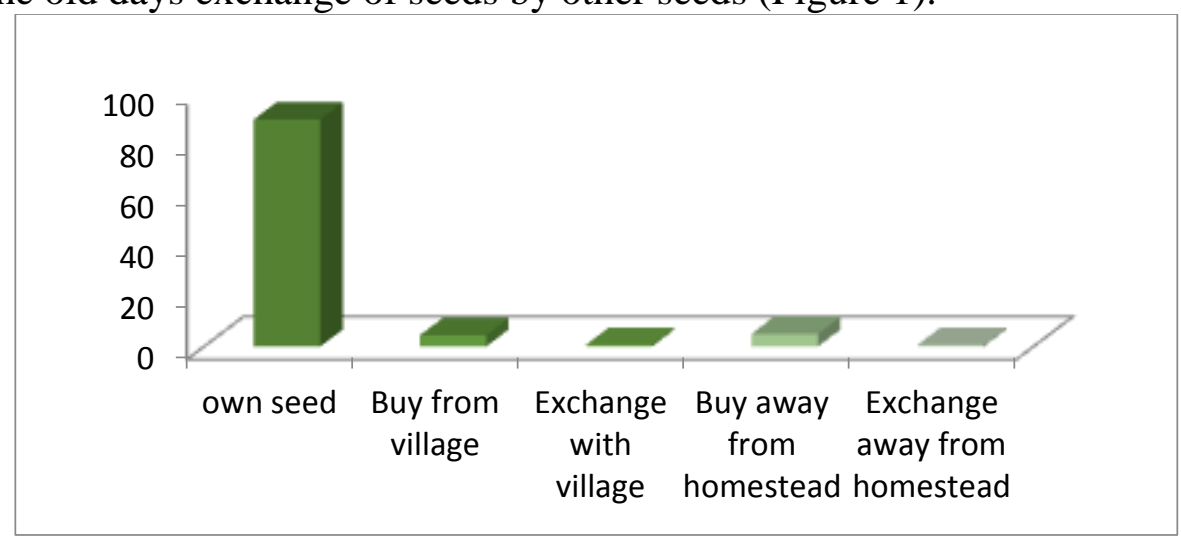

Figure 1. Seed source

Farmers in the study area store their seeds through container made of mud (gotera); sack; material made from animal skin (akimada); big material made of clay soil (insera); and also by sowing a small seed in their piece of land.

Barley seed replacement

Seeds of cereal crops can be stored for a certain periods and replaced. Farmers stated that barley seed can be stored from 1-3, 4-6 and 7-10 years with the proportion of 67.8, 28.3 and 3.9\%, respectively and replaced afterwards (Table 5). The majority of the farmers stating that they do not store seeds for long period of time are associated with the fact that they hardly produce any surplus that can be stored for longer years.

Table 1. Number of years barley seed is stored and replaced

\begin{tabular}{|l|l|l|}
\hline $\begin{array}{l}\text { Number of years barley seed is stored and } \\
\text { replaced }\end{array}$ & $\mathrm{N}$ & $\%$ \\
\hline
\end{tabular}




\begin{tabular}{|l|l|l|}
\hline $1-3$ & 122 & 67.8 \\
\hline $4-6$ & 51 & 28.3 \\
\hline $7-10$ & 7 & 3.9 \\
\hline Total & 180 & \\
\hline
\end{tabular}

\section{Role of woman in barley production}

Women play key roles in barley varietal selection and management of seed. Intra-household decision making data collected from 180 respondents related to number and type of varieties to grow, plot allocation, storage and postharvest processing is presented in Table 6.

Table 6. Intra household decision making (\%) on barley production activities.

\begin{tabular}{|l|l|l|l|l|l|}
\hline & $\begin{array}{l}\text { Number of } \\
\text { varieties }\end{array}$ & $\begin{array}{l}\text { Type of } \\
\text { varieties }\end{array}$ & $\begin{array}{l}\text { Plot } \\
\text { allocation }\end{array}$ & Storage & $\begin{array}{l}\text { Postharvest } \\
\text { processing }\end{array}$ \\
\hline Women & 1.1 & 1.7 & 2.8 & 41.1 & 49.3 \\
\hline Men & 12.8 & 20.0 & 29.4 & 4.4 & 3.4 \\
\hline Both & 86.1 & 78.3 & 67.8 & 54.5 & 47.3 \\
\hline
\end{tabular}

The decisions on number of varieties to grow (86.1\%), types of varieties to grow (78.3\%), plot allocation (67.8\%), and storage (54.5\%) were mostly decided by jointly (Table 6). However, postharvest processing is largely decided by women (49.3\%). This result is mainly in agreement with (Fetien et al., 2008) who stated that number of varieties to grow and plot allocation were mainly decided by both while post harvest processing id decided mainly by women. This result showed that though farming is mainly believed to be mainly the work of men, most decisions are made jointly by husband and wife. Though the type of variety to sow is decided jointly, in the focus group discussion they stressed that where to sow the different varieties varies between the two groups. Women usually want early maturing varieties to be sown near their home so that they will use it for hunger relief. They also consider whether they have program in the coming season or not and base their variety choice to sow. On the other hand, men give priority to sow their barley plot of land with no weed infestation, accessible for keeping away from birds attack and animal damage, and an area where there is another barley crop in the vicinity. Men believe that if there is another crop in the vicinity, damage caused by birds will be minimized and they will have common threshing ground.

From our focus group discussion the role of women in seed management as well as sayings associated with them are discussed as follows. "If there is no woman, there is no barley." This is to show that women play a role in conservation of barley. "The beauty of barley relies on woman." This is to show that women make barley ready for various purposes. "Intelligent women say to her husband that there is no barley to eat in order to keep secretly for sowing purpose." This is to show that women keep seed for sowing purpose rather than using the whole product for food or sale for market. "The owner of barley is woman." This is to show that women make barley whatever she wants. "If summer is not coming all are houses, if May is not coming all are wives." This is to show that an intelligent wife is the one who keep seed and deliver to her husband for sowing purpose. "The use of barley and wife is clearly shown in the kitchen." This is to show that barley is used for so many things prepared in the kitchen and at the same time wife in the kitchen covers everything. "Good wife is icon for her husband." This is because the wife saves seed and delivers when the need arrives. It will not cause the husband to suffer when the need for barley arises during the sowing time. All the above sayings show how much women are important in saving and maintaining barley and make ready when the need arises.

\section{Conclusion and Recommendation}

Farmers purposely maintain landraces to address various needs. The main traits farmers use to prefer a given variety over the other were maturity, yield potential, suitability for animal feed, grain size, grain color, spike length, tillering capacity, market demand, condition of the soil and product volume. Most of the recorded landraces of barley were endangered indicating the need for conservation of the landraces. The main end uses of barley in the study area were kolo, beso, tela, injera, korefe, kita and kinche.

The main factor that farmers consider to select a given variety over the others was varietal characteristics. The main varietal characteristics traits were length of the spike, size of seed, amount of seed per spike, ability to withstand disease, stand of the plant, tillering ability, number of rows, germination ability. 
The majority of farmers renew barley landraces mostly between 1-3 years. The main reason were when the ability to give product decline, in order to prevent landraces from elimination, to increase productivity, since its purity decline as the time passes by and since the if not renewed the germination ability declines. Farmers renew landraces by sowing in a fertile soil, exchanging with other farmers, sowing the seed by using compost, selecting large sized seeds and multiplying and selecting those plants with good stand and performance in the field.

In each cropping season, each household decides which variety, how much seeds and in which piece of land to sow in their farming area. Both men and women pass decisions jointly in agricultural activities. Based on this, number of varieties to grow, types of varieties to grow, plot allocation, and storage were mostly decided by jointly. Postharvest processing was largely decided by women. This result showed that though farming is believed to be mainly the work occupation of men; husband and wife make most decisions jointly.

From this study it is recommended that: breeding should be participatory by including traits farmers are interested to be incorporated in their varieties, endangered barley landraces should be collected and conserved for future improvement and the role of women should not be undermined in the conservation, selection and improvement of barley. Besides this indigenous knowledge of the farmers should be incorporated in modern breeding.

\section{Acknowledgements}

We thank all the farmers of the study area who were involved in the survey and shared their valuable knowledge. We thank University of Gondar for granting this study.

\section{Conflict Of Interest}

The authors declared there is no conflict of interest.

\section{References}

[1] Almekinders, C.J.M., Louwaars, N. and de Bruijn, G (1994). Local seed systems and their importance for an improved seed supply in developing countries. Euphytica 78:207-216.

[2] Asfaw Z (1997). Ethnobiology in enhancement and utilization of landraces. In: Fassil K., Abebe D. and Seyfu K. (Eds), Community Biodiversity Development and Conservation. Proceedings of the first meeting of the national project advisory and overseeing committee (NPAOC), coordinating unit and partner institutions. Addis Ababa, Ethiopia. pp. 62-71.

[3] Bellon MR (1996). The dynamics of crop infraspecific diversity: a conceptual framework at the farmer level. Econ. Bot. 50:26-39.

[4] Berg T (1993). The science of plant breeding-support or alternative to traditional practices? In: De Boef W., Amanor K., Wellard K. and Bebbington A. (eds), Cultivating Knowledge: Genetic Diversity, Farmer Experimentation and Crop Research. Intermediate Technology Publications Ltd., UK. pp. 72-77.

[5] Ceccarelli S, Grando S: Barley landraces from the Fertile Crescent: a lesson for plant breeders. In Genes in the Field: On-farm Conservation of Crop Diversity. Edited by: Brush SB. Boca Raton: Lewis Publishers; 2000:51-76.

[6] Eticha F, Berghofer E, Grausgruber H (2008). Characterization and Utilization of barley (Hordeum vulgare L.) landraces in the highlands of West Shewa, Ethiopia. Plant Genetic Resources: 7:154-162.

[7] Fetien A, Ann Waters-B and $A^{\circ}$ Smund B (2008). Farmers' Seed Management and Innovation in Varietal Selection: Implications for Barley Breeding in Tigray, Northern Ethiopia. Ambio 37:312320.

[8] Guarino L (1995). Secondary sources on cultures and indigenous knowledge systems. In: Guarino L., Rao V.R. and Reid R. (Eds), Collecting Plant Genetic Diversity Technical Guidelines. CAB International, Wallingford, UK. pp. 195-228.

[9] Howard, P.L. (Eds) (2003). Women and Plants: Gender Relations in Biodiversity Management and Conservation. Zed Books, London/St. Martin's Press, New York.

[10] Mulatu, E. and Zelleke, H (2002). Farmers' high maize (Zea mays L.) selection criteria: Implications for maize breeding for the Haraghe highlands of eastern Ethiopia. Euphytica 127:11-30. 
[11] Olango T, Tesfaye B, Marcello C, Mario E (2014). Indigenous Knowledge, use and on-farm management of Enset (Ensete ventricosum (Welw) Cheesman) diversity in Wolaita, Southern Ethiopia. J Ethnobiol Ethnomed. 10:1-18.

[12] Oosterhout V.S (1993). Sorghum genetic resources of small-scale farmers in Zimbabwe. In: De Boef W., Amanor K., Wellard K. and Bebbington A. (Eds), Cultivating Knowledge: Genetic Diversity, Farmer Experimentation and Crop Research. Intermediate Technology Publications Ltd., UK, pp. 89-95.

[13] Ranjil DK: Role of food tradition in conserving crop landraces on-farm. The Journal of Agriculture and Environment 2010, 11:107-119.

[14] Samberg, L. H., Fishman, L., \& Allendorf, F. W (2013). Population genetic structure in a social landscape: Barley in a traditional Ethiopian agricultural system. Evolutionary Applications 6:11331145. doi: 10.1111/eva.12091

[15] Teshome A., Torrance J.K., Baum B.R., Fahrig L., Lambert J.H. and Amase T.J (1999). Traditional farmers' knowledge of sorghum [Sorghum bicolour [Poaceae] landrace storability in Ethiopia. Econ. Bot. 53:69-78.

[16] Tilahun A, Alemu F (2017). Traits Diversity Analysis of Malt Barley (Hordeum vulgare L.) Genotypes under Irrigation at Koga of West Gojjam in Ethiopia. Mol Biol. 6:1-6. doi: 10.4172/21689547.1000190

[17] Toledo A, Burlingame B: Biodiversity and nutrition: A common path toward global food security and sustainable development. Journal of Food Composition and Analysis 2006, 19:477-483.

[18] Zerihun Yemataw, Kassahun Tesfaye, Awole Zeberga, and Guy Blomme (2016). Exploiting indigenous knowledge of subsistence farmers' for the management and conservation of Enset (Ensete ventricosum (Welw.) Cheesman) (musaceae family) diversity on-farm. Ethnobiol Ethnomed. 12(1): 34 DOI : 10.1186/s13002-016-0109-8

[19] Zewdie Bishaw, Paul C. Struik and Anthony J.G. van Gastel (2014). Assessment of on-farm diversity of wheat varieties and landraces; evidence from farmer's fields in Ethiopia. African journal of agriculture. 9:2948-2963. 